ks. Piotr Spyra

Katolicki Uniwersytet Lubelski Jana Pawła II

\title{
Kerygmat Jezusa - Dobra Nowina o człowieku i dla człowieka
}

\section{THE KERIGMA OF JESUS - THE GOOD NEWS ON MAN AND FOR MAN}

The kerygma of Jesus is the essence of his preaching, which became a foundation of christianity. It's a 'Good Message' about God, who loves, and also about who is, and who should be a human being. The kerygma is a message with joy, that gives a new life, so that evangelists called them 'Evangelium', which means 'Gospel'. In the history of The Roman Church the kerygmatic teaching was not always in the center of preaching. Therefore the author draws attention to the need of renewal and deepening of these contents. He is analysing the preaching of Jesus and shows a way, which the Church needs to discover these contents in present time, in order to contemporary men could become the participant of this Gospel.

Key words: kerigma, Jesus, man, the Good News, the Gospel.

\section{Istota problemu}

W adhortacji Evangelii Gaudium papież Franciszek pisze, że „radość Ewangelii napełnia serce i całe życie tych, którzy spotykają się z Jezusem. Ci, którzy pozwalają, żeby ich zbawił, zostają wyzwoleni od grzechu, od smutku, od wewnętrznej pustki, od izolacji"1. Słowa te są niczym innym, jak współczesną aktualizacją tego co głosił Je-

EG 1. 
zus, a co w tradycji Kościoła nazwane zostało kerygmatem. Kerygma [кń $\rho \gamma \mu \alpha$ ] dosłownie oznacza krzyk ${ }^{2}$. Jest to pierwsze głoszenie orędzia chrześcijańskiego, które należy uroczyście ogłaszać tym, którzy nie znają Boga po to, aby odkryli sens swojego życia i człowieczeństwa. Kerygmat to nie tylko najbardziej podstawowa treść Ewangelii, ale również pełne mocy wydarzenie, które sprawia, że smutni, odrzuceni, ubodzy, zniewoleni, chorzy, zmarli, trędowaci i opętani otwierają się na zupełnie nową rzeczywistość przemiany - odzyskują samych siebie $^{3}$. Dzięki temu, człowiek wyzwolony spod władzy złego może zacząć swoje życie od nowa, nadając mu nowy kierunek - ku Bogu i drugiemu człowiekowi.

Nie dziwi zatem fakt, że Mateusz i Marek działalność Jezusa z Nazaretu nazwali Ewangelią - Dobrą Nowiną. Słowo to było obecne w języku rzymskich cesarzy, którzy uważali się za panów świata, jego wyzwolicieli i zbawców. Wychodzące od nich orędzia zwane były evangelium, bez względu na to, czy ich treść była radosna i przyjemna ${ }^{4}$. To, co pochodziło od cesarza miało w swoim zamyśle być orędziem zbawczym, a więc nie tylko zwykłą wiadomością, lecz przesłaniem zmieniającym świat na lepsze. Skoro Ewangeliści posłużyli się tym terminem, oznaczało, że właśnie spełnia się to, do czego niesłusznie wysuwają roszczenia cesarze, podający się za bogów - w osobie Jezusa dokonuje się pełne mocy orędzie, które jest nie tylko słowem, ale rzeczywistością. Tutaj człowiek naprawdę dostępuje przemiany życia: odkrywa sens i cel swojego istnienia, tu wypełniają się jego najgłębsze oczekiwania i tęsknoty.

Z perspektywy dwóch tysięcy lat można odnieść wrażenie, że nowość, jaką wniósł Jezus w życie człowieka została w jakiś sposób zapomniana, bądź też niedoceniana, nawet w kręgach chrześcijańskich. Jose H. Prado Flores (ur. 1947), założyciel Szkół Nowej Ewangelizacji św. Andrzeja (SESA) uważa, że przez wiele lat działalności duszpasterskiej Kościół zagrzebywał denar głoszenia kerygmatycznego, nie zyskując przy tym odsetek i trwoniąc kapitał dany od Jezusa ${ }^{5}$. Największym bogactwem Kościoła jest Ewangelia łaski, a Jego wielka misja polega na głoszeniu tej Ewangelii aż po krańce ziemi (Mk 16, 15-16).

J. H. Prado Flores, Nowi ewangelizatorzy dla Nowej Ewangelizacji, Poznań 2013, s. 65;

Zob. G Ryś, Jezusowa nowa ewangelizacja, [w:] Kerygmatyczny impuls w Kościele, Gubin 2012, s. 14. do Przemienienia, Kraków 2007, s. 51. 
Jednak od czasów reformacji Marcina Lutra to światło było ukryte pod korcem, porzucony został wymiar kerygmatyczny, kierując uwage na dogmat, kult i sakramenty. Wskutek tego dla wielu osób, również chrześcijan, to co objawił Jezus stało się nieatrakcyjne i nieżyciowe. W konsekwencji mamy paradoksalną sytuację: Kościół naucza i katechizuje tych, którzy jeszcze nie narodzili się na nowo ${ }^{6}$.

Jeśli chcemy, aby Ewangelia, czyli Dobra Nowina stała się skuteczna w życiu człowieka, musimy na nowo odkrywać treści głoszone przez Jezusa i nauczyć się kolejności przedstawiania tych prawd. Niezwykle ważnym narzędziem, pozwalającym uporządkować przesłanie Jezusa i Kościoła jest podział na kerygmat (pierwsze głoszenie) oraz katechezę (nauczanie, utwierdzanie w wierze). Pierwotny Kościół głosząc Ewangelię do pogańskiego i judaistycznego świata zaczynał zatem najpierw od kerygmatu, aby zrodzić w słuchaczach żywą wiarę, a następnie stopniowo utwierdzał w tej wierze poprzez katechezę ${ }^{7}$. Chrześcijanie w pierwszych wiekach przejmowali, potwierdzali i przeżywali absolutną nowość ewangelicznego orędzia, a widząc potrzeby neofitów i wiernych, którzy dopiero co przyjęli wiarę, zauważali wielką rolę katechezy stanowiącej dla nich etap nieodzownego rozwoju i środek konieczny do tego, by doświadczenie mogło osiągnąć swą dojrzałość ${ }^{8}$. Owocem tego był niezwykle dynamiczny rozwój wspólnot chrześcijańskich w pierwszych wiekach, którego nie zahamowały nawet prześladowania. O tym ważnym rozróżnieniu świadczą chociażby pisma Klemensa Aleksandryjskiego (150-215), który w Pedagogu, nawiązując do 1 Kor 3, 1-3, wyjaśnia, że Pawłowe słowo „mleko” oznacza przepowiadanie posiadające charakter kerygmatu (użycie gr. słowa kerygma), podczas, gdy ,pokarmem stałym” jest wiara solidnie ugruntowana, na podobieństwo fundamentu, jako owoc katechezy (użycie gr. słowa katechesis).

Aby katecheza przyniosła obfity owoc, musi stać na swoim miejscu, zawsze po przepowiadaniu kerygmatycznym. Aby w człowieku wzrastało życie, musi być ono najpierw zrodzone. W przeciwnym razie następuje podawanie drogich potraw w postaci doktryny, moralności i prawowitej nauki tym, którzy jeszcze są umarli, bo nie doświadczyli

E. Tardif, J. H. Prado Flores, Jezus jest Mesjaszem, Łódź 1991, s. 107.

J. H. Prado Flores, Jak ewangelizować ochrzczonych, Łódź 1993, s. 14.

P. Nonis, Ewangelizacja a katecheza, [w:] Nowa ewangelizacja. Kolekcja Communio 8(1993), Poznań 1993, s. 99.

9 R. Murawski, Stosunek ewangelizacji do katechezy $w$ dziejach katechezy, [w:] S. Dziekoński (red.), Ewangelizować, czy katechizować, Warszawa 2002, s. $15-16$. 
Życia w obfitości, które Chrystus przyszedł przynieść na ziemię ${ }^{10}$. Wielkim wyzwaniem dla współczesnego Kościoła jest zatem odkrycie na nowo znaczenia kerygmatu i zreformowania przepowiadania. Nie chodzi jednak o zepchnięcie katechezy do roli drugorzędnej, ale o pokazanie, że kerygmat i katecheza są dwoma filarami podtrzymującymi jedną konstrukcję wiary. Każdy z nich ma swoje miejsce, cel i treść, które należy wyróżnić, uszanować i docenić ${ }^{11}$. Jakąś wewnętrzną więzią łączą się one ze sobą i uzupełniają ${ }^{12}$. Połączenie ze sobą ewangelizacji i katechezy jest w naszych czasach zadaniem Kościoła najtrudniejszym, największym i wymagającym wielkiego zaangażowania. Od tego zależy, czy Kościół ożyje na nowo, ofiarowując człowiekowi Ewangelię zbawienia i przekształcając świat na lepsze, czy będzie chylił się ku upadkowi, a wraz z nim ludzkość zniszczona grzechem i strukturami $z^{\prime}{ }^{13}$. Wymaga to $z$ kolei nowych narzędzi, nowych sposobów głoszenia, a przede wszystkim odkrycia na nowo mocy kerygmatu i świadomości różnic tych dwóch form przepowiadania.

W tym celu chcemy przyjrzeć się kerygmatowi Jezusa, który jest Dobrą Nowiną o Bogu, człowieku i dla człowieka, fundamentem, dokumentem tożsamości i swoistym DNA chrześcijaństwa, samą czynnością głoszenia Ewangelii, jak i jej najbardziej podstawową treścią ${ }^{14}$. Spośród ogromnego bogactwa treści kerygmatycznego przepowiadania Jezusa o człowieku, zostaną tu przedstawione najbardziej podstawowe tematy, które powinny się znaleźć w centrum przepowiadania i zainteresowania Kościoła.

\section{Definicja kerygmatu}

Termin 'kerygmat' pochodzi od greckiego czasownika 'kerryssein' i oznacza: głosić, ogłaszać, podawać do publicznej wiadomości, wołać głośno, nawoływać, proklamować, obwieszczać ${ }^{15}$. Częstym podmiotem

$10 \quad$ E. Tardif, J. H. Prado Flores, Jezus jest Mesjaszem, dz. cyt., s. 107. Zob. EN 17-23, EG 14-15.

$12 \quad \mathrm{CT} 18$

13 P. Nonis, Ewangelizacja a katecheza, dz. cyt.., s. 100.

14 J. Chmiel, Pojęcie i rola kerygmatu $w$ pierwotnym Kościele, „Ruch Biblijny i Liturgiczny" 33(1980), s. 59; J. H. Prado Flores, Idźcie i ewangelizujcie ochrzczonych, Brwinów 1993, s. 7-8; Tenże, Jak ewangelizować ochrzczonych, op. cit., s. 14; Tenże, Nowi ewangelizatorzy..., dz. cyt., s. 65.; Por. A. Paciorek, Kerygmat $w$ Biblii, [w:] Encyklopedia Katolicka, Lublin 2008, t. 8, kol. 130-1361.

15 Zob. G. Friedrich, Keryx, kerysso, kerygmat, [w:] G. Kittel, G. Friedrich (red.) Theologisches Wörterbuch zum Neuen Testament, Stuttgart 1933-1979, t. 3, s. 682-717. 
tego czasownika był herold, który „obwieszczał” zwycięstwa w zawodach sportowych, nadania zaszczytów i godności. Ważnym elementem znaczenia omawianego słowa jest to, że treść zawarta w takowym obwieszczeniu staje się faktem z chwilą podania jej do publicznej wiadomości ${ }^{16}$. Biblia grecka Starego Testamentu (Septuaginta) nie wykazuje wielkiego zainteresowania tym terminem, gdyż słowo to występuje tam jedynie 34 razy i służy na przetłumaczenie aż sześciu słów hebrajskich. Jednym ze znaczeń jest właśnie opisanie działalności herolda (Rdz 41, 43; Est 6, 9.11; Dn 3, 4; 5, 29; 2 Krn 24, 9; 4 Krl 10, 20). W Nowym Testamencie słowo keryssein oznacza akcję, samo obwieszczenie, ogłoszenie tego, co zapowiadały proroctwa Starego Testamentu ${ }^{17}$. Nie zapowiada czegoś, co ma dopiero nastąpić w przyszłości, ale wieść, którą ogłasza staje się automatycznie rzeczywistością już obecną teraz. W tym samym momencie, w którym obwieszcza rok łaski, treść ta faktycznie wchodzi w życie. Dlatego jest to słowo z mocą, które ma moc przemieniać życie tych, którzy słuchają tego słowa. W sensie szerokim jest to centralne przesłanie Dobrej Nowiny, w sensie ścisłym - przepowiadanie Apostołów skierowane do pogan; uroczyste i publiczne proklamowanie zbawienia w Jezusie Chrystusie połączone z wezwaniem do wiary i w konsekwencji do nawrócenia ${ }^{18}$. Przepowiadanie to bierze swój wzór i początek w kerygmacie Jezusa, dlatego niezbędne jest głębokie studium Ewangelii głoszonej przez Niego. Nie chodzi jednak o rozumowe przyswajanie doktryny, ale o dotarcie do serca człowieka, aby ten przez wiarę chciał przyjąć osobę Jezusa w swoim życiu, co prowadzi w konsekwencji do doświadczenia nowego życia w Duchu Świętym. W ramach kerygmatu nie mówi się o czymś, ale o Kimś. Stąd też jedną z pierwszych definicji chrześcijaństwa nie było określenie „,filozofia”, ani „,doktryna”, ani też „nauka”, ale Życie (zob. Dz 5, 20). Kerygmat niejako opanowuje człowieka i działa na niego $\mathrm{z}$ wielką mocą ${ }^{19}$. Takie głoszenie Ewangelii ze swej natury wywołuje reakcję, jaką można zaobserwować u Żydów po mowie Piotra: „Przejęli się do głębi i powiedzieli: Cóż mamy czynić bracia" (Dz 2, 37). Jego prowokacyjny charakter zmusza człowieka do dania Jezusowi odpowiedzi wiary lub odrzucenia Go.

16

R.Rubinkiewicz,Nowotestamentalna idea przepowiadania,[w:] tenże, Królestwo Boże jest wśród was. Wybrane zagadnienia z teologii biblijnej, Lublin 2010, s. 159.

$17 \quad$ Tamże.

18

19

Por. W. Przyczyna, Teologia ewangelizacji, Kraków 1992, s. 115.

Zob. S. Dyk, Biblijne podstawy ewangelizacji, [w:] W. Przygoda(red.), Świadectwo w stużbie ewangelizacji, Lublin 2012, s. 31-53. 


\section{Treści kerygmatu Jezusa}

Jeśli można w jakiś sposób podsumować przesłanie Dobrej Nowiny głoszonej przez Jezusa, będą to słowa: Królestwo Boże. Centralnym tematem przepowiadania Jezusa było orędzie o królewskim panowaniu Boga (basileia tou theu ${ }^{20}$. Może to potwierdzić informacja statystyczna: słowa „Królestwo Boże” pojawiają się w Nowym Testamencie 122 razy, z tego 99 razy w trzech Ewangeliach synoptycznych, przy czym $90 \mathrm{z}$ tych tekstów to słowa Jezusa ${ }^{21}$.

Idea, że Bóg ma królować w życiu osobistym i społecznym Izraelitów, że ma w ich codzienności zajmować to samo miejsce, jakie w sąsiednich narodach zajmowali królowie, nie była „nowa” w czasach Jezusa ${ }^{22}$. Miała swe głębokie korzenie w Starym Testamencie. Hebrajskie słowo malkut oznaczało dla ludzi Wschodu rzeczywistą zdolność rządzenia, funkcję królewskiego i realnego panowania. Nigdy nie rozumiano go w sposób abstrakcyjny, jak na Zachodzie, lecz zawsze jako coś dynamicznego, coś co się przejawia w konkretnych rzeczach. Mówiąc zatem o Królestwie Bożym Jezus głosi po prostu samego Boga - Boga żywego, który może w konkretny sposób działać w świecie i historii i właśnie teraz działa w Jego osobie na korzyść człowieka. Stąd te dwa tematy - Bóg i człowiek - są ze sobą związane. Dla słuchaczy nauki Jezusa płynie mocny komunikat: Bóg istnieje i jest Bogiem, który interesuje się człowiekiem, kocha go, chce go zbawić i wejść z nim w niezwykłą zażyłość, pełną przyjaźni i ufności. Nadszedł czas, kiedy w sposób doskonalszy od wszystkiego, co było dotychczas, ukazuje się w historii jako jej Pan, jako Bóg żywy ${ }^{23}$. To, co widzą Apostołowie i uczniowie, to obecność samego Boga, który przychodzi zwyciężać zło i przekształcić świat swoją miłością ${ }^{24}$. Czyni to z myślą o człowieku i wszystkich jego sferach. Dlatego Jezus, kiedy posyła swoich uczniów na pierwszą misję (Mt 10,1-16) wydaje nakaz, aby o tym Królestwie, które nadeszło nie tyle mówić, opowiadać czy debatować, ale je proklamować i wykrzyczeć z wielką mocą - Jezus poleca im (w.7): „Krissete! Głoście kerygmat!". W innych miejscach Ewangelii wiele razy pada sformułowanie, że On sam chodził po Galilei i głosił (krisseon) Ewangelię Bożą (Mk 1, 14).

J. Gnilka, Jezus z Nazaretu. Orędzie i dzieje, Kraków 1997, s. 108.

J. Ratzinger - Benedykt XVI, Jezus z Nazaretu, dz. cyt., s. 52.

G. Ryś, Jezusowa nowa ewangelizacja..., dz. cyt., s. 13.

Tamże.

Papieska Komisja Biblijna, Biblia a moralność. Biblijne korzenie postępowania chrześcijańskiego, Kielce 2009, s. 67.
} 
Analizując ideę Królestwa głoszonego przez Jezusa, Jose H. Prado Flores wyróżnia następujące jego cechy ${ }^{25}$ :

\section{Jezus Chrystus Dobrą Nowiną o Miłości Bożej}

Królestwo Boże jest nie tylko obietnicą, ale obecnością samego Jezusa. Wiąże się to z faktem Wcielenia Bożego Syna - „Słowo stało się ciałem i zamieszkało między nami" (J 1, 14). Marek swoją Ewangelię rozpoczyna słowami „Ewangelia Jezusa Chrystusa” (Mk 1, 1), przez co chce powiedzieć, że Jezus Mesjasz jest Dobrą Nowiną. Orędzie Jezusa nie miałoby takiej mocy i siły przekonywania, gdyby nie to, że On sam żył tym wszystkim, co głosił. Całe Jego życie było najwspanialszą nauką i jedną wielką „czynnością” ewangelizacyjną, dlatego nie bał się powiedzieć: uczcie się ode Mnie (Mt 11, 29) ${ }^{26}$. Przyglądając się życiu Jezusa nasuwa się wniosek, że nie sposób oddzielić od siebie Jego misji i Jego Ja, gdyż Syn Boży całkowicie utożsamia się z tym, o czym mówi ${ }^{27}$. W ten sposób przesłanie Dobrej Nowiny stało się nie tylko teorią, ale praktyką i stylem życia najpierw Jezusa, a potem Jego uczniów. Sposób, w jaki Jezus przeżywał swe ludzkie życie, rozwiązywał konflikty, podchodził do różnych sytuacji, Jego postawa wobec możnych, Jego zachowanie w obliczu pokus, Jego odpowiedź na cierpienie, Jego sposób podejścia do śmierci, odnoszenia się do osób i instytucji, wreszcie każdy aspekt Jego życia i każda zasada życiowa jest Dobrą Nowiną wprowadzoną w czyn. Widać to w wielu sytuacjach, które ukazują harmonię słów i czynów Jezusa ${ }^{28}$ :

- zamiast jedynie mówić o przebaczeniu (Mt 18, 21-35), zawsze przebaczał: Marii Magdalenie (Łk 8, 1-3), Piotrowi (J 21, 15-19), a w sposób szczególny swoim oprawcom (Łk 23, 34a);

- kochał wszystkich, a szczególnie dwunastu Apostołów, ubogich, grzeszników; gdy Jego uczniowie prosili Go, by nauczył ich modlić się, nie podał suchej formuły, ale otworzył swe serce na Boga (Łk 11, 1-13);

- przyszedł, aby służyć, a nie aby Mu służono (Mt 20,28) i udowadnia to myjąc swoim uczniom nogi (J 13, 1-17);

- czynił jedynie dobro i w swoim sercu nie miał obłudy (Dz 10,38), nie przyjął łatwej drogi triumfalizmu mesjańskiego, wyrzekł się bycia królem, aby stać się sługą wszystkich $(\mathrm{J} 6,20)$;

J. H. Prado Flores, Cómo Evangelizar a los Bautizados, México 2013, s. 19-28.

S. Dyk, Biblijne podstawy ewangelizacji, dz. cyt., s. 31 . 
- nie sprzedał swej wolności, aby przypodobać się tym, którzy dzierżyli władzę państwową, czy religijną (Łk 23, 1-12);

- umiał odnosić się doskonale do Boga, jako Ojca, ponieważ doświadczył, co znaczy być umiłowanym synem, w którym Bóg ma upodobanie (Mk 9, 6);

- był wolny od jakiegokolwiek przywiązania do rzeczy materialnych; będąc bogatym staje się ubogim, i to tak ubogim, że nie ma gdzie głowy skłonić (Mt 4, 8-9), ani też tronu jaki chcieli ofiarować $\mathrm{Mu}$ Żydzi po rozmnożeniu chleba $(\mathrm{J} 6,15)$;

- był zawsze w zgodzie z naturą i całym stworzeniem; żyje razem ze zwierzętami polnym i szanuje równowagę ekologiczną, pozwalając rosnąć pszenicy i kąkolowi (Mt 13, 24-30. 37-43). Daje nawet jeszcze jedną szansę drzewu figowemu, które nie daje owoców (Łk 13, 1-9).

\section{Bóg jest miłującym Ojcem}

Na przestrzeni wieków troska o zachowanie świętości i czci Boga u Izraelitów przeobraziła się w coś w rodzaju tabu, do tego stopnia, że wśród prostego ludu zrodziła się świadomość wielkiej przepaści między Bogiem a człowiekiem. Człowiek z szacunku i bojaźni wobec Boga nie powinien wymawiać Jego świętego Imienia. Stąd też w miejsce imienia Boga używano słów zastępczych: Imię, Miejsce, Chwała, Niebo, Potęga, Wysokość, Majestat, co sprawiło, że o Bogu wyrażano się w sposób bezosobowy, jak Absolut, który nie posiada imienia ${ }^{29}$. Owo poczucie transcendencji i przepaści pomiędzy Bogiem a człowiekiem doprowadziło do przekonania, że dobro i błogosławieństwo ze strony Stwórcy można osiągnąć tylko przez ludzki wysiłek, jak m.in. składanie ofiar, modlitwę, dziesięciny czy post.

Jezus na wiele sposobów burzy wyobrażenia współczesnych mu Izraelitów, którzy odeszli od pierwotnej idei Boga. Czyni to poprzez przypowieści, w sposób szczególny tryptyk Łk 15 (o zagubionej owcy, miłosiernym ojcu i zgubionej drachmie), gdzie ukazuje uczniom Ojca, który zawsze przebacza grzechy, któremu zależy na każdym człowieku i cieszy się z nawrócenia swoich synów. $Z$ tym Ojcem można rozmawiać używając czułych słów. Poprzez naukę Modlitwy Pańskiej (Mt 6, 9-13) Jezus włącza uczniów w swoje doświadczenie Boga jako Taty (aram. Abba - tak zwracały się dzieci do swojego ojca, Mk 14, 36). Ten sposób modlitwy jest absolutną nowością w dziejach Izraela, gdyż w ich dotychczasowym przekonaniu tak bliski przystęp do Boga nie

$29 \quad$ L. Stachowiak, Starotestamentalna koncepcja Boga, RTK 19(1972) z. 1 s. 70; J. Kudasiewicz, Ewangelie synoptyczne dzisiaj, Ząbki 1999, s. 287. 
był możliwy dla grzesznego człowieka ${ }^{30}$. Współczesne badania egzegetyczne wykazały, że $A b b a$ jest autentycznym i oryginalnym powiedzeniem Jezusa ${ }^{31}$. W tym jednym słowie objawia On Boga, jako bliskiego i dobrego Ojca, który choć święty i nieogarniony, jest przede wszystkim Ojcem, kochającym swoje dzieci. Ten Ojciec, który jest w niebie każe świecić słońcu i zsyła deszcz na sprawiedliwych i niesprawiedliwych $(\mathrm{Mt} 5,45)^{32}$. Co więcej, Jezus jako prawdziwy Syn Boży nie zostawia tego synostwa tylko dla siebie, ale uznaje za przybranych synów Ojca wszystkich, którzy czynią pokój (Mt 5, 9), miłosiernych (Łk 6, 35) i sprawiedliwych wskrzeszonych z martwych (Łk 20,36) ${ }^{33}$. A do tych, którzy nie są sprawiedliwi, z miłości posyła swojego Syna, ponieważ to nie zdrowi, ale chorzy potrzebują lekarza (Mt 9,12), aby zbawienie zapowiedziane w Starym Testamencie stało się udziałem każdego syna Abrahama (Łk 19, 9-10). Można zauważyć zatem, że Jezus przynosi obraz Boga, który z jednej strony pozostaje transcendentny, doskonały i całkowicie różny od człowieka, z drugiej strony zaś objawia się jako Ojciec pełen dobroci, miłosierdzia i przebaczenia. Dzięki tej nauce ojcostwo Boga zostaje pogłębione i ukazane w nowy sposób: królowanie Boże jest królowaniem miłości, natomiast chwała Boża przejawia się w wolności kochania i przebaczania ${ }^{34}$.

\section{Posłany do grzeszników}

Jedną z najpiękniejszych, ale i najtrudniejszych do przyjęcia przez współczesnych była prawda o tym, że Bóg w sposób szczególny kocha tych, którym brakuje wszystkiego ${ }^{35}$. Do takich ludzi zaliczają się grzesznicy, którzy przez swoje uczynki w opinii współczesnych byli wykluczeni z dziedziczenia Bożych obietnic pomyślności i szczęścia. Jednakże Jezus nauczał, że nie potrzebują lekarza zdrowi, lecz Ci, którzy się źle mają (Mt 9, 9-13). Stąd ci, którzy mieli ogromne problemy, aby przybliżyć się do Boga, stają tak naprawdę w centrum Jego zainteresowania, gdyż okazuje się, że to sam Bóg poszukuje zagubionych ludzi. Takie pojęcie Boga dla wielu pobożnych Żydów było nie do

30 Zob. J. Lourenço, Sens wzywania imienia Boga $w$ dawnym judaizmie, ComP 14(1994) s. 51.

31 J. Kudasiewicz, Ewangelie synoptyczne dzisiaj, dz. cyt., s. 288.

32 J. H. Prado Flores, Jak ewangelizować ochrzczonych, dz. cyt., s. 23.

33 H. Renard, P. Grellot, Syn Boży, [w:] X. Léon-Dufour (red.), Stownik Teologii Biblijnej, Poznań 1994 (dalej: STB), s. 920.

34 W. Kasper, Jezus Chrystus, Warszawa 1983, s. 76.

35 J. H. Prado Flores, Cómo Evangelizar..., dz. cyt. s. 20. 
pomyślenia. Aby ukazać ogrom miłosierdzia Ojca, Jezus opowiada trzy wielkie przypowieści, zwane „Ewangelią w Ewangelii”: o zgubionej owcy, zgubionej drachmie i miłosiernym ojcu ${ }^{36}$. Wielkim zaskoczeniem dla słuchaczy jest postawa dobrego pasterza, który zostawia 99 owiec na pustkowiu i wyrusza, aby szukać jednej zagubionej oraz postawa kobiety, która gubiąc jedną drachmę przetrząsa cały swój dom, aby ją odnaleźć. Podobnie w przypowieści o synu marnotrawnym w jednym zdaniu została ukazana cała głębia i skuteczność miłosierdzia Boga ${ }^{37}$ : „A gdy był jeszcze daleko, ujrzał go jego ojciec i wzruszył się głęboko; wybiegł naprzeciw niego, rzucił mu się na szyję i ucałował go" (Łk $15,11)$. Ojciec najpierw dostrzega swego syna i widzi jego nędzę. $Z$ takiego spojrzenia rodzi się głęboka litość. Następnie on sam wychodzi na spotkanie powracającego syna, przyjmuje do domu i wyprawia na jego cześć ucztę radości. To miłosierdzie Ojca realizuje Jezus, który je „wciela i uosabia" 38 . Nie odwiedza w Jerychu synagogi, aby spotkać się z ,porządnymi ludźmi”, ale udaje się do domu największego grzesznika w okolicy - Zacheusza (Łk 19, 1-10). Siada do stołu z ludźmi, którzy mają złą reputację i przechodzi przez ziemię Samarytan. Jezus zaznacza przy tym, że nikt, kto zwraca się do Niego nie zostanie odrzucony (Mt 11, 28-30). W ten sposób wszyscy ludzie mają gwarancję Boskiej akceptacji, jakiekolwiek by nie były ich grzechy w przeszłości. Grzech nie jest przeszkodą w zbliżeniu się do Boga. Wręcz przeciwnie - może być traktowany jako punkt zwrotny, który przybliża do przebaczenia ${ }^{39}$.

\section{Zbawienie jest darmowe}

Podstawą przepowiadania Jezusa jest Dobra Nowina o zbawieniu. Niesie ona ze sobą przebaczenie dla grzeszników i nowe życie dla wszystkich ludzi bez wyjątku. Podczas, gdy Jan Chrzciciel przepowiada straszny sąd Boży, Jezus głosi początek zbawienia, które radykalnie odmieni życie człowieka, jego potrzeby, pragnienia, a przede wszystkim - poprzez nieskończoną miłość Bożą - dokona przebaczenia grzechów ${ }^{40}$. Cały system religijny Izraela skupiał się wokół przesłania: musisz być dobry, aby zbliżyć się do Boga, albo przynajmniej musisz

G. Ryś, Rekolekcje - modlitwa, post, jałmużna, Kraków 2013, s. 91.

37 J. Kudasiewicz, Ewangelie synoptyczne dzisiaj, dz. cyt., s. 305.

DM 2.

J. H. Prado Flores, Cómo Evangelizar..., dz. cyt., s. 20. 
się oczyścić, aby nie być unicestwiony ogniem świętości Boga ${ }^{41}$. Centralnym przesłaniem Jezusa było natomiast: zbawienia nie można ani kupić, ani na nie zasłużyć. Jest to dar darmowy, wynikający z miłości i miłosierdzia Boga (Łk 15), dlatego nie można go za nic kupić, ani zdobyć za jakieś zasługi. Nie zależy ono od zewnętrznego wypełniania przepisów prawa, postów, wypracowanych cnót (Mt 23, 1-36), czy liczby przepracowanych godzin, ale pochodzi przede wszystkim z hojności Boga. Gdyby tak było, wystarczałoby własne działanie, aby uczynić siebie sprawiedliwym (Łk 18, 9-14). Zbawienie porównane jest do uczty (Mt 22,1-14), na którą zaproszeni są wszyscy bez wyjątku, dobrzy i źli. Otrzymają je Ci, którzy stają przed Bogiem w swojej grzeszności (J 8, 1-11), w prawdzie (J 4, 17), ubodzy (Mt 5,3) i zupełnie bezsilni jak łotr (Łk 23, 29-43), który nie był w stanie zbawienia niczym kupić, ukraść, ani zasłużyć na nie, a Jezus podarował mu je za darmo. To prawda, że trzeba modlić się o nadejście tego Królestwa (Mt 6, 10), szukać go nieprzerwanie ( $\mathrm{kk} 13,24 ; \mathrm{Mt} \mathrm{7,13),} \mathrm{być} \mathrm{nieustannie} \mathrm{gotowym} \mathrm{na} \mathrm{przyjęcie}$ go (Mt 24, 44; 25, 10.13; Łk 12, 35-37), jak i wzywać Boga dzień i noc, aby zostać wysłuchanym (Łk 18, 7). Jednak człowiek sam z siebie nie jest w stanie sprawić, aby to Królestwo stało się namacalnym faktem i objawiło się w pełni ${ }^{42}$. Zależy to całkowicie od łaski i potęgi Bożej.

\section{Wartość osoby}

W nauczaniu Jezusa można zauważyć Jego troskę o każdego człowieka, a w sposób szczególny o tych najmniejszych, pokrzywdzonych i najsłabszych (Mt 18, 6; Mt 25, 40, Łk 10, 21). Do tej kategorii zaliczyć można przede wszystkim:

- dzieci, które nie uznawano za osoby, dopóki nie ukończyły trzynastego roku życia były szczególnym przedmiotem Jego upodobania i uwagi (Mt 18, 10) ${ }^{43}$; w nauczaniu Jezusa stają się nawet wzorem do naśladowania dla tych, którzy chcą wejść do Królestwa (Mt $18,3)$.

- ubogich, gdyż Jezus przekonuje, że człowiek jest wartością nie dzięki temu, co posiada, ale dzięki temu kim jest; świadczy o tym chociażby przypowieść o bogaczu, który ufał swoim bogactwom i Łazarzu, którego imię oznacza: ten, który ufa Bogu (Łk 16, 19-31) oraz „opcja na rzecz ubogich”, którą tak wyraźnie widać w relacji Łukaszowej Ewangelii;

\footnotetext{
$41 \quad$ J. H. Prado Flores, Cómo Evangelizar..., dz. cyt., s. 24.

42 Tamże, s. 31.

43 J. H. Prado Flores, Jak ewangelizować ochrzczonych, dz. cyt., s. 24.
} 
- chorych i odtrąconych; tu miłość Jezusa wyraża się nie tyle w słowach, co konkretnych działaniach. Uzdrawia teściową Piotra ( $\mathrm{Mk}$ 1, 29-39) i uzdalnia ją do służby, sprawiając, że odczuła nie tylko swą wartość, ale że jest niezbędna dla innych; uzdrawia również człowieka z uschłą ręką ( $\mathrm{Mk} 3,1-6)$, pokazując przy okazji, że szabat, wszelkie przepisy i instytucje są dla człowieka, a nie odwrotnie; przez postawienie tego człowieka na środku synagogi domaga się również, aby istota ludzka była zawsze w centrum zainteresowania;

- grzeszników; kobieta przyłapana na cudzołóstwie (J 8, 1-11, która według oskarżycieli powinna zasłużyć na karę śmierci jest najlepszym przykładem, że Jezusowi zależy, aby nikt nie zginął (J 17, 12). Jezus przyjął ją nie jako grzesznicę, ale jako kobietę i tak też ją nazywa, rehabilitując ją poprzez swe przebaczenie i zaufanie, że nie wróci do grzechu, ponieważ byłoby to pomniejszeniem jej osoby $^{44}$;

- kobiety; w ówczesnym judaizmie kobiety nie należały o kategorii osób, które darzono wielkim szacunkiem; były one w cieniu mężczyzn, a niekiedy nawet lekceważone; pobożny Izraelita w czasie liturgii synagogalnej recytował następujące błogosławieństwo: „Błogosławiony bądź o Panie, Boże nasz, Królu wszechświata, że nie stworzyłeś mnie niewiastą" ${ }^{45}$. W lekturze ewangelicznych tekstów można zauważyć niespotykane dotąd zrównanie mężczyzny i kobiety w sprawie rozwodu. Do tej pory Prawo Mojżeszowe uprzywilejowywało pozycję mężczyzny, który mógł oddalić żonę. Jezus wprowadza tu radykalną zmianę: nie zezwala na żadne zrywanie małżeństwa (Mk 10, 9-12), odwołując się do pierwotnego zamiaru Bożego w dziele stworzenia $(\mathrm{Rdz} 2$, 24), w którym wyraźnie potwierdzona jest równość pod każdym względem mężczyzny i kobiety ${ }^{46}$. Jezusowi towarzyszyły w drodze kobiety, które „usługiwały im, [udzielając] ze swego mienia” (Łk 8, 3). Ewangelista Łukasz daje wyraźnie do zrozumienia, że należały one do ścisłej wspólnoty wierzących, traktowane były jako słuchaczki nowej nauki na równi z dwunastoma Apostołami i że ich towarzyszenie Jezusowi było konstytutywnym czynnikiem

\section{Tamże.}

45 J. Kudasiewicz, Ewangelie synoptyczne dzisiaj, dz. cyt., s. 268-269.

46 R. Rubinkiewicz, Pozycja społeczna kobiety w świetle Ewangelii, [w:] tenże, Królestwo Boże jest wśród was. Wybrane zagadnienia z teologii biblijnej, Lublin 2010, s. 169. 
powstawania wspólnoty pierwotnego Kościoła ${ }^{47}$. Dopuszczenie kobiet do grona uczniów Jezusa było czymś tak niesłychanym w zwyczajach rabinicznych owych czasów, że mogło spowodować anatemę ze strony ówczesnych żydowskich władz religijnych ${ }^{48}$;

- pogan; Królestwo Boże urzeczywistnia się ponad przynależnością do społeczności Izraela. Jezus chętnie odwiedza tereny znienawidzone przez współczesnych mu Żydów (m.in. Samarię - J 4, 1-42), stawia za wzór wiary tych, którzy w opinii judaistycznej są ludźmi gorszej kategorii (miłosierny Samarytanin - Łk 10, 30-37) i zapowiada, że zbawienie jest dostępne dla wszystkich narodów $(\text { Łk 4, 16-30) })^{49}$.

\section{Czystość intencji}

To, na co szczególnie zwracał uwagę Jezus, zwłaszcza u faryzeuszów, to czystość intencji. Wielkim odkryciem ewangelicznym jest fakt, że nie wystarczy czynić tego, co uważamy za dobre, lecz konieczna jest czystość intencji, z którą działamy. To motywacja, z którą dokonujemy naszych czynów nadaje im wartość ${ }^{50}$. Faryzeusze pościli, modlili, dawali jałmużnę, lecz mieli niewłaściwe intencje (Mt 6,5). Taka postawa nie daje żadnej zasługi w królestwie. Dlatego Jezus bardzo mocnymi słowami atakuje faryzejskie zakłamanie, gdyż:

- pościli zgodnie z Prawem, ale zaniedbywali swoje twarze, aby cały świat był świadom ich poświęceń,

- odprawiali długie modlitwy, ale ich wzrok nie był utkwiony w Bogu, bo inaczej nie staraliby się o uznanie w oczach ludzi,

- dbali, by ich pobożne praktyki były dostrzegane po to, by ludzie dobrze o nich mówili51 .

W przypowieści o faryzeuszu i celniku (Łk 18, 9-14) Jezus demaskuje postawę faryzeusza, który kierując modlitwę do Boga „w duszy”, tak naprawdę wpatrzony jest w siebie samego (pros auton) ${ }^{52}$. Ponad uczynki człowieka, nawet te dobre (posty i dziesięciny) ważniejsza jest

\footnotetext{
${ }_{47}$ J. Ratzinger - Benedykt XVI, Jezus z Nazaretu..., dz. cyt., s. 61.

R. Rubinkiewicz, Pozycja społeczna kobiety wświetle Ewangelii..., dz. cyt., s. 170.

S. Mędala, Czas Jezusa. Ewangelia wedtug św. Łukasza, w: tenże (red.), Wprowadzenie $w$ myśl $i$ wezwanie ksiag biblijnych. Praca zbiorowa pod red. ks. J. Frankowskiego, Część 8 - Ewangelie synoptyczne, Warszawa 2006, s. 278-279.

J. H. Prado Flores, Jak ewangelizować ochrzczonych, dz. cyt., s. 24.

Tenże, Formacja uczniów, Łódź 1992, s. 63-64.

52

A. Jankowski, Królestwo Boże w przypowieściach, Poznań - Warszawa 1981, s. 60 .
} 
więc sprawiedliwość, miłosierdzie i wiara. Można dać niewiele Bogu, jak uboga wdowa (Mk 12, 38-44), a w Bożych oczach będzie to ofiara o wiele bardziej cenna niż to, co dają bogaci tego świata. Bóg bowiem nie patrzy na to ile dajemy, ale ile pozostawiamy sobie. Jeśli ma się prawidłowe intencje można uzdrawiać w szabat (Mk 3, 1-6), można nawet jeść wszelkie nieczyste pokarmy (Mk 7,21-23), ponieważ zepsucie idzie z wnętrza na zewnątrz, a nie odwrotnie. Podstawą oceny uczynków jest nie to, co się robi, ale intencja $z$ jaką wykonuje się dane działanie. Czystość zamiarów polega na czynieniu wszystkich rzeczy w jednej intencji i to umotywowanej ewangelicznie. Brak tej czystości będzie polegał na dołączeniu do działalności apostolskiej naszych własnych interesów lub korzyści osobistych.

\section{Miłość ponad wszystko - wszyscy jesteśmy braćmi}

Prawo Królestwa Niebieskiego i nowej ludzkości jest sformułowane najpełniej w Kazaniu na Górze (Mt 5-7). Dostrzec je można również w konkretnych działaniach Jezusa, gdzie pokazywał swoim uczniom, że ponad wszelkim Prawem i przepisami religijnymi stoi miłość. Aby otworzyć oczy ślepym faryzeuszom, czasami jadł nie umywszy rąk (Mk 7, 14-23), zrywał kłosy (Mt 12,1-14) i uzdrawiał w szabat (Łk 13, 10-17), ponieważ to, co w Prawie jest naprawdę istotne, polega na wypełnianiu miłości bliźniego, a nie na technicznym i bezdusznym wypełnianiu, pozbawionym istoty rzeczy ${ }^{53}$. Jezus sam mówi, że Jego misją jest odkryć prawdziwy i duchowy sens przepisów - „Nie przyszedłem znieść, ale wypełnić" (Mt 5,17 ), a więc samemu zrealizować Torę i pokazać co jest punktem kulminacyjnym woli Bożej zawartej $\mathrm{w}$ Prawie ${ }^{54}$. Dlatego daje Nowe przykazanie, nakazuje abyśmy miłowali jedni drugich tak, jak On sam nas umiłował i jest czymś, co wyróżnia Jego uczniów (J 13,34). Choć przykazanie miłości występuje u wszystkich synoptyków (Mk 12, 28-31; Mt 22, 34-40, Łk 10, 25-28), to u Mateusza zostało zaakcentowane w szczególny sposób. W polemice z faryzeuszami jeden z nich pyta: „Nauczycielu, które przykazanie w Prawie jest największe? On mu odpowiedział: Będziesz miłował Pana Boga swego całym swoim sercem, całą swoją duszą i całym swoim umysłem. To jest największe i pierwsze przykazanie. Drugie podobne jest do niego: Będziesz miłował swego bliźniego jak siebie samego. $\mathrm{Na}$ tych dwóch przykazaniach opiera się całe Prawo i Prorocy" (Mt 22, 34-40). Mateusz wyraźnie koncentruje i skupia całe Prawo na jednym

$53 \quad$ J. H. Prado Flores, Jak ewangelizować ochrzczonych, dz. cyt., s. 27. 
punkcie, w którym zawarte jest wszystko - na przykazaniu miłości. Wielkie przykazanie jest istotą Prawa i Proroków i jest to nie tylko etyczna maksyma, ale również jego zasada teologiczna ${ }^{55}$. Oznacza to, że z przykazania miłości może być egzegetycznie wyprowadzona cała Tora. Boża wola nie tylko osiąga punkt kulminacyjny w tym przykazaniu, ale całkowicie i zupełnie się w nim zawiera. Oba przykazania miłości (Pwt 6,5; Kpł 19, 18) są nie tylko największe, lecz całe Prawo i Prorocy „zawisły” (krematai) na nich, jak drzwi na zawiasach ${ }^{56}$. Ten kto je wypełnia, wypełnia wszystkie inne prawa.

Konsekwencją miłości Boga jest też miłość do człowieka. Normą etyczną dla uczniów Jezusa ma być złota reguła postępowania (Mt 7, 12) - „Wszystko więc, co byście chcieli, żeby wam ludzie czynili, i wy im czyńcie. Albowiem na tym polega Prawo i Prorocy". Jest to wyraźna aluzja do przykazania miłości (Mt 22, 40). W tej regule streszczają się wszystkie nakazy Kazania na Górze, które są interpretowane w znaczeniu przykazania miłości. Uczniowie Jezusa mają miłować nie tylko współbraci (Mt 7, 15), ale wszystkich ludzi, nawet wrogów i prześladowców $(5,38-48)^{57}$. Tak jak Bóg przebacza winy człowiekowi z miłości, tak też i my winniśmy przebaczać naszym braciom (Mt 6, 12.14). Dopiero wtedy, gdy wypełni się ten obowiązek, można złożyć ofiarę miłą Bogu (Mt 5, 25-26). Miłość ma tak fundamentalne znaczenie w relacjach pomiędzy braćmi, że w relacji Mateusza brak tej miłości poprzez gniew jest porównany do morderstwa (Mt 5, 21), natomiast krytyka i sądzenie bliźnich zasługuje na surowy sąd Boży (Mt 7, 1-6).

\section{Pascha}

W czasach Jezusa święto Paschy gromadziło w Jerozolimie wszystkich Izraelitów, aby złożyć we wspólnej ofierze, a potem spożyć baranka wielkanocnego. Była to pamiątka wyjścia Ludu Wybranego z Egiptu, czyli wyprowadzenia ich z niewoli ${ }^{58}$. Zapowiadała również ostateczną interwencję Boga w przyszłości, związaną ze zbawieniem przyniesionym przez oczekiwanego Mesjasza. Jej świętowanie stało się okazją do jednej z wielkich pielgrzymek Izraelitów w ciągu roku do

\footnotetext{
55 J. Kudasiewicz, Jezusowe prawo mitości, „Ethos” 43(1988), s. 58-62.

Tenże, Ewangelie synoptyczne dzisiaj, dz. cyt., s. 228.

$57 \quad$ J.Stępień, Miłość nieprzyjaciót jako specyficzny rys duchowości Nowego Testamentu, [w:] J. Chmiel, T. Matras (red.), Studium Scripturae anima theologiae. Prace ofiarowane Księdzu Profesorowi Stanisławowi Grzybkowi, Kraków, S. 302-310. 
Jerozolimy. Droga Jezusa miała wyznaczony cel właśnie w Jerozolimie. Wiele razy zapowiadał, że tam wypełni się Jego misja (Łk 13, 32-33; Łk 18, 31). W mieście Dawida ma spożyć gorąco oczekiwaną Paschę (Łk 22, 15). Ten ważny moment zapowiadał wcześniej wielokrotnie i nazwał go Jego ,godziną” (J 7, 30). W Wieczerniku, dzień przed swą męką, Jezus spożywa wieczerzę paschalną wraz z Apostołami, stosując się do wszystkich przepisów Starego Przymierza. Ten znany Apostołom obrzęd wypełnia jednak nową treścią. „Tej nocy, kiedy został wydany, wziął chleb i dzięki uczyniwszy połamał i rzekł: «To jest Ciało moje za was [wydane]. Czyńcie to na moją pamiątkę». Podobnie, skończywszy wieczerzę, wziął kielich, mówiąc: «Ten kielich jest Nowym Przymierzem we Krwi mojej. Czyńcie to, ile razy pić będziecie, na moją pamiątkę!»" (1 Kor 11, 23-26). W tych słowach zawiera Nowe Przymierze, stając się nowym Barankiem Paschalnym, który zgładzi grzechy całego świata. Poprzez ofiarę ze swojego życia i przelanie krwi uwolni wszystkich spod władzy szatana (Ga 1, 4; J 8, 12n Ef 1, 6-7; Rz $3,24)$. W ten sposób okaże największy dowód swojej miłości, oddając życie za przyjaciół (J 15, 13). Trzeciego dnia jednak zmartwychwstanie, pokonując śmierć i stając się królem nieba i ziemi. Aby wszyscy poznali to misterium odkupienia i mieli udział w Nowym Przymierzu wysyła swoich uczniów, aby głosili Jego śmierć i Zmartwychwstanie, przekazując Dobrą Nowinę na wszystkie krańce świata (Mk 16, 15).

W ciągu Starego Testamentu Bóg wielokrotnie zapowiadał zawarcie Nowego Przymierza w przyjściu Mesjasza. Jednym z takich proroctw są słowa przekazane prorokowi Jeremiaszowi - „Oto nadchodzą dni wyrocznia Pana - że zawrę z domem Izraela i z domem judzkim nowe przymierze" (Jr 31, 31). Słowa te wypełniły się w osobie Jezusa, który swoją krwią zapieczętował Nowe Przymierze, mające już nigdy nie być zerwane: „(...) Pijcie z niego wszyscy, bo to jest moja Krew Przymierza, która za wielu będzie wylana na odpuszczenie grzechów" (Mt $26,27-28)$. Krew Jezusa unicestwiła winy i żaden wyrok nie wisi już nad grzesznikami, którym przebaczono. Zbawienie, na które oczekiwał naród Izraela staje się rzeczywistością. Owa zbawcza obecność i działanie Jezusa Chrystusa, wyrażane przez idee Królestwa Bożego, znajduje swoją kontynuację w tajemnicy Kościoła, który został przez Niego założony i ciągle jest ożywiany przez Ducha Świętego ${ }^{59}$.

$59 \quad$ R. Ptak, Królestwo Boże. Realizacja zbawczego planu Boga..., dz. cyt., s. 121. 


\section{Obietnica Ducha}

Jezus rozpoczął swoją misję głoszenia Dobrej Nowiny od namaszczenia Duchem Świętym podczas chrztu w Jordanie (Mt 3, 13-17). Duch Boży wypełniał go, dając mu przeświadczenie bycia umiłowanym Synem Ojca. Ta moc z wysoka umożliwiła mu nie tylko czynienie cudów, spełnianie woli Ojca, ale dała siłę, by dać życie za tych, których kochał. Jeszcze za życia mówił uczniom o „obietnicy Ojca” dla wszystkich, którzy w niego wierzą. Dlatego w najbardziej uroczyste święto, stojąc na dziedzińcu świątyni zawołał: Jeśli ktoś jest spragniony, niech przyjdzie do mnie i pije. A powiedział to mówiąc o Duchu Świętym, którego mieli otrzymać wierzący w Niego (J 7, 37-39). Ten Duch Prawdy przypomni Jego słowa $(\mathrm{J} 14,26)$ i będzie źródłem Nowego życia dla dzieci Bożych (Rz 8, 5-16). Stanie się on Parakletem - Obrońcą i zostanie już na zawsze w tych, którzy go pragną $(J 14,16)$. Będzie przekonywał świat o grzechu, sprawiedliwości i sądzie. Dlatego pożyteczne jest odejście Jezusa, bo dzięki temu Ojciec spełni swoją obietnicę zesłania tej mocy z wysoka na uczniów.

Duch Święty będzie również aktualizował dzieło Jezusa w Kościele. Dzięki Niemu spotkanie z Jezusem będzie zawsze zbawczym wydarzeniem, pełnym świeżości i dynamizmu, które to będzie można doświadczyć we wspólnocie wierzących. Ta nieustanna nowość będzie związana przede wszystkim z obietnicą Ducha Świętego, który sprawi, że uczniowie będą czynili większe rzeczy niż sam Jezus (J 9, 14). On również będzie dawcą i twórca jedności w Kościele - Mistycznym Ciele Chrystusa $^{60}$. W mocy Ducha Świętego Królestwo Boże uobecniające się we wspólnocie eklezjalnej jest „,zaprogramowane” na wzrost i ma charakter eschatologiczny. Trzeba cierpliwie czekać, aż wyda zapowiedziane owoce i wypełni się zapowiedź nowej Jerozolimy (Ap 3,12; 21,2) - pełni Bożej obecności, gdzie całe stworzenie będzie brać udział w realizacji przymierza, kiedy ukażą się nowe niebo i nowa ziemia ${ }^{61}$.

\section{Formacja uczniów}

Jezus wielokrotnie podkreślał, że w Królestwie Bożym nie żyje się indywidualnie, lecz wspólnotowo. Tym co łączy i wyróżnia uczestników Królestwa są wartości ewangeliczne, a w sposób szczególny braterska

\footnotetext{
60 U. Szwarc, Duch Święty jako życiodajna zasada (fundament biblijny), [w:] J. Nagórny, J. Gocko (red.), Duch Święty w postudze Kościoła wobec świata. Materiaty $z$ Duszpasterskich Wykładów Akademickich $w$ Katolickim Uniwersytecie Lubelskim 27-28 sierpnia 1998, Lublin 1999, s. 45-46.
}

Zob. I. de la Potterie, Nowe, [w:] STB s. 565. 
miłość. W związku z tym Królestwo nie ogranicza się tylko do ludzkich serc, ale jest konkretną rzeczywistością obecną na różnych płaszczyznach ludzkiego życia ${ }^{62}$. Jako zaczyn Królestwa Jezus wybrał dwunastu Apostołów, z którymi się nie rozstawał (Mk) i którzy będą fundamentem Nowego Izraela (Mt). Piotrowi wręczył klucze Królestwa (Mt 16, 19), aby otwierał drzwi wiary zarówno dla Żydów (Dz 2,14 do 36), jak i pogan (Dz 10-11), a tym samym zgromadził w jedno wszystkie dzieci Boże, które są rozproszone (J 11, 52). Dzięki temu misja Jezusa, czyli zbawienie wszystkich ludzi, wszystkich czasów i wszystkich krańców ziemi mogła się urzeczywistnić, bo uformował On i swoich uczniów na mistrzów, tak aby oni byli w stanie formować kolejnych uczniów, a przez to stale poszerzać Królestwo Boże ${ }^{63}$. W dniu Zmartwychwstania ujawnił uczniom sekret swojej wizji pasterskiej i objawił swą taktykę: formować uczniów w taki sam sposób, w jaki On sam to uczynił. W ten sposób trzy lata publicznej działalności Jezusa w zupełności wystarczyły, aby Jego głos pokonał barierę czasu i przekroczył ograniczenia przestrzeni. Do tej misji uczniowie zostali napełnieni Duchem Świętym (Mt 28, 28-19), wyposażeni w charyzmaty (Mk 16, 16-18), a celem jest przynosić obfity i trwały owoc (J 15, 8-16). Właśnie to czynienie uczniów jest ostatnim i największym przykazaniem Jezusa, zwanym „,wielkim rozesłaniem”. W opinii J. H. Prado Floresa to ważne przykazanie powinno być nazwane raczej ,wielkim zaniedbaniem”, gdyż tego polecenia nie wypełniamy tak jak trzeba ${ }^{64}$. Twórca szkół nowej ewangelizacji uważa, że skupiliśmy się na drugorzędnych (choć też ważnych) rzeczach w Kościele, zamiast całą energię wkładać w formację prawdziwych uczniów Jezusa.

\section{Podsumowanie}

Celem misji Jezusa było zbawienie człowieka i wszystkich ludzi ${ }^{65}$. Obwieszczając nową erę mesjańską stał się On zarówno lekarzem chorych, uzdrowicielem serca, jak również tym, który będzie podnosił złamanych na duchu (por. Ps 147, 3) oraz przynosił pokój i pełnię życia we wspólnocie uczniów (J 14, 2; J 10, 10). Objawił w ten sposób również Boga, w którego świetle pokazał kim jest i kim powinien być

\footnotetext{
$62 \quad$ J. H. Prado Flores, Cómo Evangelizar..., dz. cyt., s. 25.

63 J. H. Prado Flores, Formacja uczniów, dz. cyt., s. 92.

64 Tamże, s. 95; tenże, Nowi ewangelizatorzy dla nowej ewangelizacji, dz. cyt., s. $78-126$.

65 Tenże, Jak ewangelizować ochrzczonych, dz. cyt., s. 32.
} 
człowiek. Dzięki Jezusowi posiadamy dziś integralną wizję człowieka jako jedności cielesno-psychiczno-duchowo-społecznej.

Na podstawie tych informacji warto zrewidować treść i kolejność przepowiadania Ewangelii - Dobrej Nowiny o człowieku przez dzisiejszy Kościół. Ponieważ jest on w dalszym ciągu Kościołem Apostolskim, ustanowionym przez Jezusa, musi zatem przekazywać to, co otrzymał od Niego i Apostołów ${ }^{66}$. Dzisiejsza Ewangelia nie może być więc nowa co do treści, gdyż nie istnieje Ewangelia różna od tej, jaka była głoszona przez samego Jezusa i przekazana przez Apostołów. Treścią głoszenia dziś ma być ten sam Jezus, jedyny Zbawiciel człowieka, Pan i Mesjasz, który umarł, zmartwychwstał i został uwielbiony. Dobra Nowina to przesłanie o wielkiej miłości Boga do nas, który gdy byliśmy jeszcze grzesznikami, wydał Swego Syna na śmierć, aby każdy, kto w Niego wierzy miał życie. Ma ona przynieść nadzieję w każdej sytuacji, we wszystkich okolicznościach życia, a źródłem tej nadziei jest pokonanie śmierci przez Zmartwychwstanie Jezusa ${ }^{67}$. Ewangelia to osoba Jezusa, nie „coś”, ale „Ktoś” - Jezus Chrystus, który oddał swoje życie za nas, ale zmartwychwstał i żyje dalej w swoim Kościele, uzdrawiając, przynosząc wolność, podnosząc na duchu etc. Nie potrzebujemy więc nowej Ewangelii. Już otrzymaliśmy ogromny skarb i bogactwo, ale trzeba go umieć odkryć, wydobyć i wykorzystać, żeby nie żyć jak biedacy i żeby nasi bracia nie uciekali do innych wspólnot chrześcijańskich w poszukiwaniu pierwszego głoszenia Ewangelii ${ }^{68}$.

Kerygmat, który ma być głoszony dzisiaj ma być zatem głoszeniem życia, śmierci i Zmartwychwstania Jezusa. Nie chodzi jednak o to, by opowiadać o jakichś wydarzeniach sprzed dwóch tysięcy lat, lecz o to, by mówić w sposób aktualny, aby ten kto słyszy o Jezusie mógł tu i teraz doświadczyć zbawienia. Kluczem do wejścia w ten Boży plan jest decyzja: albo żyć obciążony oskarżeniami, w bezsensie życia i śmierci, albo być dziedzicem błogosławieństw w Jezusie, dzięki wierze. Aby ją podjąć, należy pokazać człowiekowi Boga, który dziś kocha, dziś uzdrawia i dziś wyzwala. Nie osiągniemy tego celu powtarzając dosłownie formuły nowotestamentalne, jak archeolog, który odkrywa rzeczy zamierzchłych czasów, czy też przypisując im jakieś magiczne formu$ł^{69}$. Chodzi o to, by w procesie rodzenia wiary głosząc Jezusa odnieść się do najgłębszych potrzeb i tęsknot drzemiących w człowieku, aby

\footnotetext{
66 Tenże, Nowi ewangelizatorzy dla nowej ewangelizacji, dz. cyt., s. 76.

$67 \quad$ E. Tardiff, J. H. Prado Flores, Jezus jest Mesjaszem, dz. cyt., s. 102. 
wyjść naprzeciw ludzkiemu oczekiwaniu na zbawienie. Trzeba mówić, że człowiek w chwili obecnej potrzebuje zbawienia i że w tej samej chwili może go doświadczyć, jeśli dziś uwierzy i nawróci się. Wtedy otrzyma tego samego Ducha Świętego, którego otrzymali Apostołowie dwa tysiące lat temu i dzięki temu otworzy się przed nim perspektywa zupełnie nowego życia.

Wielkim zadaniem Kościoła jest więc najpierw aktualizacja Ewangelii do dzisiejszych czasów, a więc użycie takich słów, które są bliskie i zrozumiałe dla współczesnego człowieka oraz odwołanie się do takich doświadczeń, które są mu znane, aby mógł najpierw zidentyfikować swój życiowy problem, a potem znaleźć rozwiązanie w osobie Jezusa. Jeśli zabraknie takiej postawy, może się okazać, że ewangelizator mówi o problemach oderwanych od ludzkiej egzystencji i współczesnych problemów. Wtedy Ewangelia staje się nieżyciowa i przestaje być tym, czym powinna być - Dobrą Nowiną o Bogu, człowieku i dla człowieka.

Słowa kluczowe: kerygmat, Jezus, człowiek, Dobra Nowina, Ewangelia. 